\title{
Reflexões sobre um processo de tradução: história, teatro e pintura em uma obra de Rafael Alberti
}

Reflexiones sobre un proceso de traducción: historia, teatro y pintura en una obra de Rafael Alberti

\section{Guilherme Assis dos Reis}

Universidade Federal de Alfenas - Unifal -Minas Gerais - Brasil

\author{
Kátia Aparecida da Silva Oliveira
}

Universidade Federal de Alfenas - Unifal -Minas Gerais - Brasil

\begin{abstract}
Resumo: Este trabalho tem como objetivo refletir sobre o processo de tradução crítica que realizamos da obra teatral Noche de Guerra en el Museo de Prado (1956), do escritor espanhol Rafael Alberti (1902-1999), a primeira realizada em língua portuguesa, conforme temos notícia. Essa peça, que se situa temporalmente no momento da Guerra Civil Espanhola, é construída a partir de uma relação interartes que faz dela original e inovadora, o que motivou o interesse por sua tradução e difusão entre os leitores brasileiros. Neste artigo, discutimos a natureza do texto teatral e a problemática que envolve traduzir o texto dramático, especialmente no caso de uma obra que dialoga com outras artes. A partir de nossa experiência de tradução, destacamos o interesse em estabelecer uma tradução que considerasse o público brasileiro e que permitisse uma aproximação com uma história e cultura com as quais, talvez, não tivesse intimidade. Buscamos discutir e apresentar, assim, as dificuldades que foram encontradas ao traduzir uma obra cuja finalidade deixa de ser apenas a representação cênica, mas também a construção de um discurso interartes.
\end{abstract}

Palavras-chave: Noche de Guerra en el Museo del Prado; Rafael Alberti; Tradução Crítica; Tradução de teatro; Interartes.

Resumen: Este trabajo tiene como objetivo reflexionar sobre el proceso de traducción crítica que realizamos de la obra teatral Noche de Guerra en el Museo de Prado (1956), del escritor español Rafael Alberti (1902-1999), la primera realizada en lengua portuguesa, según que tenemos noticia. Esta pieza, que se ubica temporalmente en el momento de la Guerra Civil Española, es construida a partir de una relación interartes que la hace original e innovadora, lo que nos motivó el interés por su traducción y difusión entre os lectores brasileños. En este artículo, discutimos el tipo del texto teatral y la problemática que involucra la traducción del texto dramático, especialmente en el caso de una obra que dialoga con otros tipos de arte. A partir de nuestra experiencia de traducción, destacamos el interés en establecer una traducción que llevara en consideración el público brasileño y que le permitiera una aproximación con una historia y cultura con las cuales, quizás, no tenga intimidad, quizá. Buscamos discutir y presentar, por consiguiente, las dificultades que encontramos en la traducción de una obra cuya finalidad no está únicamente en la representación escénica, como también en la constitución de un discurso intereartes.

Palabras-llave: Noche de Guerra en el Museo del Prado; Rafael Alberti; Traducción Crítica; Traducción de teatro; Interartes. 


\section{Introdução}

A obra Noche de Guerra en el Museo de Prado (1956) é uma peça teatral que Rafael Alberti (19021999) escreve durante seu exílio na América Latina, que se inicia depois da Guerra Civil Espanhola (19361939), forçado pelo governo ditatorial que é implantado na Espanha. Da poesia à dramaturgia, Rafael Alberti utilizou-se de diversas manifestações artísticas para se expressar e para representar seus fortes sentimentos em relação à sua terra natal e para destacar suas posições políticas.

Alberti começa a se interessar pela escrita após anos de dedicação à pintura, a partir de seu contato com grandes nomes da vanguarda espanhola do século XX. Alberti conta com uma grande produção literária, sendo autor de obras poéticas como Marinero en tierra (1924), A la pintura (1948), Las 4 estaciones (1985), e também das obras teatrais Fermín Galán (1931), La Gallarda (1945), Noche de Guerra en el Museo de Prado (1956), entre outros. O poeta, dramaturgo e pintor viveu para as artes e deixou um grande legado para a literatura espanhola.

Alberti escreve Noche de Guerra en el Museo de Prado depois de mais de vinte anos exilado do seu país. Depois de uma viagem pela Europa e com ganas de voltar à Espanha, o pintor escreve essa peça, na qual remonta um dos momentos iniciais da Guerra Civil que dividiu a Espanha no começo século passado. A obra tem um enredo que se desenvolve em meio aos bombardeios que a cidade de Madrid sofreu e retrata uma das missões de que o autor participou junto à Alianza de Intelectuales Antifascistas, organização política da qual era membro.

Dividida em um prólogo e ato único, como diz o título original, a obra de Alberti traz à tona a retirada dos quadros do Museu para que sobrevivessem aos ataques aéreos. Para contar a história, os personagens pintados nos quadros ganham vida e se posicionam a fim de defender uma Espanha à beira de mais uma guerra. Ressalta-se, aqui, que a grande maioria dos quadros remetem às guerras decorrentes das invasões napoleônicas a Espanha (1808) e daí surge uma interessante relação intertextual.
O autor estabelece uma complexa relação entre Pintura, Teatro e História, que transforma a peça em uma grande obra. Alberti cria uma maneira única de explanar o contexto histórico da segunda metade dos anos 30 através do teatro, dotando a obra de grande valor literário e cênico. Pensando nisso, realizamos a Tradução Crítica de Noite de Guerra no Museu do Prado (2019), com o intuito de aproximar o público brasileiro dessa peça até então sem tradução.

Considerando que alguns temas e pinturas abordados na peça poderiam não ser conhecidos pelo público brasileiro, reunimos com a tradução um estudo introdutório dividido em quatro partes que prepara 0 público brasileiro para a peça que irá ler. A tradução foi desenvolvida em um projeto de Iniciação Científica (PIBIC/CNPq), pela Universidade Federal de Alfenas, iniciada em agosto de 2018, com final em julho de 2019 e ainda não foi publicada.

Neste trabalho apresentamos algumas reflexões acerca do texto teatral e das especificidades que envolvem a sua tradução. Para tal, recorremos a Sábato Magaldi (1994), Ryngaert (1996) e Pascolati (2019), que nos apresentam definições pertinentes ao texto teatral como texto literário e texto voltado para a representação cênica. Os trabalhos de Bassnett (1980) e Zurbach (2021) foram essenciais para que pensássemos a tradução do texto teatral com finalidade não unicamente cênica, mas também como texto literário e, a partir disso, poder analisar todas as dificuldades que foram vivenciadas ao longo do processo tradutório.

\section{Rafael Alberti e Noche de Guerra en el Museo de Prado}

Rafael Alberti (1902-1999) foi um homem das artes. Escritor, dramaturgo e pintor espanhol, nasceu na pequena cidade de El Puerto de Santa María, em Cádiz, onde desde muito cedo começou a demonstrar seu interesse pelas artes através da criação de retratos dos navios que lá desembarcavam. No entanto, é em 1917, quando seu pai se muda para Madrid, que Alberti tem seus primeiros contatos com as grandes obras de arte espanholas. A ida para a capital permitiu que 
Alberti tivesse a oportunidade de entrar em contato com o Museu do Prado, lugar no qual ele começa a desenvolver suas habilidades artísticas (CERIOGLI, 2001, p. 12). O futuro escritor passava horas no museu, analisando os quadros expostos, para que depois pudesse realizar seus próprios trabalhos. Devido aos longos períodos em que passava por lá, o Museu do Prado tomou uma grande importância para a vida de Alberti. Mais do que um espaço histórico, o museu se tornou uma escola e uma segunda casa para ele.

Em 1923, Rafael Alberti passa a se dedicar à escrita. Nesse ano, o agora escritor espanhol produz seu primeiro livro de poesias: Mar $y$ tierra, posteriormente renomeado como Marinero en tierra (1924). É também nesse ano em que ele se encontra com os outros artistas, posteriormente conhecidos como integrantes da Generación de 27.

Ao lado de grandes nomes da literatura e dramaturgia espanhola, como Frederico García Lorca (1828-1936), Ernestina de Champourcín (1905-1999), Jorge Guillén (1893-1984) e María Teresa León (19031988), além de pintores, cineastas e músicos, Alberti participou de uma renovação artística. Esse encontro foi essencial para que ele se interessasse ainda mais pela escrita e passasse a desenvolvê-la cada vez mais (CERIOGLI, 2001, p. 13). Durante os primeiros momentos como escritor, Alberti dedicou-se quase exclusivamente à poesia. Entretanto, alguns anos depois, durante a Segunda República espanhola, Alberti passa a ter mais contato e a escrever textos teatrais.

Naquele momento, a Espanha vivia tempos sombrios. As mudanças entre as ideologias do governo anunciavam o momento ferrenho que o país viveria nos anos seguintes. Em paralelo a isso, o escritor, assim como sua esposa, a também escritora Maria Teresa León, se filiaram ao Partido Comunista em 1931. As ideologias de Alberti estavam cada vez mais refletidas em suas obras, e isso ficou mais evidente quando passou a se interessar pelo teatro.

Os partidos da esquerda, naquele período, apostavam no teatro como meio de politização da massa. Com isso, Alberti foi enviado, juntamente com Maria Teresa León, para uma viagem pela Europa a fim de "estudar os novos movimentos cênicos" (CERIOGLI, p. 14). Nessas viagens o escritor entrou em contato com grandes dramaturgos, como Bertolt Brecht (18981956), que se tornaria um dos amigos mais influentes de Alberti, chegando até mesmo a ajudar em algumas de suas obras teatrais, como em Noche de Guerra en el Museo de Prado, obra que traduzimos e que motiva as reflexões apresentadas nesse trabalho.

A referida obra foi escrita em 1956, quando Alberti e sua família já viviam seu exílio rio-platense, em decorrência da guerra e da ditadura que se desenvolveram na Espanha. Noche de Guerra, assim como grande parte da obra de Alberti, evoca eventos ocorridos na Guerra Civil Espanhola. Mayra Carvalho (2016, p. 145), em um estudo das poesias de Alberti, aponta que esse era um tema recorrente nos escritos do autor, principalmente nos anos em que a Guerra acontecia. Segundo ela, através das poesias de Alberti, inseridas no Romances de la Guerra de España (1938), é possível identificar alguns eventos acontecidos durante a Guerra: nos poemas vemos, por exemplo, "a tomada da residência do Duque de Alba pelos milicianos, o papel da Catalunha e do País Basco e o engajamento de poetas de todo o mundo à causa republicana." (CARVALHO, 2016, p. 145). Essa maneira poética de documentar os eventos da guerra é retomada no teatro e em Noche de Guerra.

É importante destacar que a Espanha de 1936, momento no qual a peça é situada, é marcada pela guerra e por uma história recente de poder alternado entre a esquerda e direita, que provoca drásticas mudanças no país. A guerra civil eclode porque, em 1931, com a instauração da Segunda República, um governo majoritariamente socialista ascende ao poder e as reformas propostas não foram bem aceitas pela população espanhola, principalmente pela demora com a qual eram aplicadas, e isso causou insurreições por todo o território espanhol. O descontentamento com o governo esquerdista cresce tanto que, em 1933, a Espanha elege um governo inteiramente direitista. Esse governo durou até 1936, quando novas eleições trouxeram a esquerda de volta ao poder, causando, assim, o descontentamento da direita conservadora que aplicou um golpe, em 17 de julho daquele ano, 
dando origem à Guerra Civil. (CASANOVA; ANDRÉS, 2000, p. 83-95).

Alberti viveu esse momento crítico atuando como secretário da Alianza de Intelectuales Antifascistas, sob a presidência de José Bergamín. Já nessa época tem-se registros das primeiras obras escritas por Alberti que retratavam a Guerra Civil na forma de poesias (CARVALHO, 2016). Os apoiadores do governo eleito, principalmente, viveram um momento de muita resistência, já que sofriam diversos ataques vindos da direita. Dentre esses apoiadores estava a Alianza de Intelectuales Antifascistas, que, no intuito de proteger o legado intelectual espanhol, desenvolveu diversas missões pela Espanha, sendo uma delas a retirada das obras de arte do Museu do Prado, fato que inspirou a criação da peça aqui estudada.

Como expõem Ceriogli e Buades Juan (2001, 2011), várias localidades da cidade de Madrid sofriam com bombardeios e o Museu era um destes focos. Alberti escreve, posteriormente, durante seu exílio, sobre a noite em que ele e seus companheiros e companheiras da Alianza de Intelectuales Antifascistas foram ao museu. Embora tenha um teor fictício, no qual os personagens dos quadros escondidos tomam vida, a peça retoma a noite em que se inicia a Guerra e, mais especificamente, remonta os bombardeios que a cidade de Madrid sofria sob ataques dos insurgentes.

O Museu é o cenário principal dessa peça, como já explicita o título. Os acontecimentos (do prólogo e do ato único) tomam vida no salão principal da chamada Casa da Pintura, que acaba se tornando um espaço de guerra com o desenrolar da história. $O$ prólogo recebe a função de situar o leitor/espectador nesse espaço e de marcar a importância do museu para a cidade de Madrid. Essa obra não é a primeira na qual o autor intersecciona as artes. Em sua antologia Las 4 estaciones, como proposto por Mohallem e Oliveira (2017) em sua análise, já podemos ver como Alberti consegue unir seu fazer artístico com seus pensamentos políticos. "Alberti não só expressa sua posição ideológica em relação ao contexto histórico republicano, como também retrata todo anseio, desilusão e conflitos daqueles que viveram nesse período" (MOHALLEM; OLIVEIRA, 2017, p. 93). Novamente, Alberti utiliza essa relação interartes na construção da peça teatral que traduzimos.

Essa peça, além de contar a história específica da Guerra Civil, estabelece uma relação dialógica com as guerras napoleônicas, ocorridas em 1808. Alberti consegue trazer os personagens das telas para defender a Espanha dos séculos XIX, contra Napoleão, e $X X$, contra os insurgentes que lutavam contra a república, fazendo conectando as duas grandes guerras civis que dividiram o povo espanhol e que 0 colocaram na rua, em luta armada, para defender seus ideais (CERIOGLI, 2001).

Pode-se dizer, assim, que o Noche de Guerra é uma peça que une o Teatro, as Artes Plásticas e ainda dialoga com a História. São três áreas diferentes que se integram, na obra de Alberti, para manter viva a memória de um período que não pode ser esquecida. $A$ obra, para além de manter a memória viva do povo espanhol, cumpre o papel de divulgar o que aconteceu ali para o mundo, principalmente através das traduções que se realizam a partir dela.

\section{Dificuldade para a tradução: traduzir o teatro e traduzir a pintura.}

"Sem obra dramática, não há teatro", diz Sábato Magaldi (1994, p. 15) em seu livro Iniciação ao Teatro. O autor propõe que o texto de teatro é essencialmente pensado com a representação no palco como produto final. Em suas palavras, "o texto deve ser escrito para a eficácia do espetáculo" (MAGALDI, 1994, p. 22). O texto teatral se sustenta, então, no diálogo assim como o texto do romance se sustenta na prosa e o poema nos versos. A ideia geral que $o$ autor brasileiro transmite é a de que o texto teatral deve ser escrito já pensando no ator que o encenará. (MAGALDI, 1994, p. 15-23)

Por outro lado, em Jean-Pierre Ryngaert (1995), encontramos uma discussão sobre as especificidades do texto de teatro. Segundo ele, o teatro e o texto teatral contam com diversas possibilidades entre si: "fazer teatro de tudo é poder fazer teatro de nada, ou de pouca coisa." (RYNGAERT, 1995, p. 6). O 
autor propõe essa reflexão quando diz que, durante os anos 60-80, o espetáculo reduziu o texto e começou a priorizar os outros elementos que compõem a cena, como o cenário, efeitos visuais ou figurinos, por exemplo. Logo, para Ryangaert, o texto de teatro é um texto "transformável", isto é, o texto de teatro apresenta uma maleabilidade grande o suficiente para que seja usado em diversos momentos: seja num palco ou como estudo literário.

É nos estudos de Sônia Pascolati (2019), onde encontramos o equilíbrio entre as duas teorias. A autora reflete que "quando se questiona a autonomia do texto dramático em relação à representação ou vice-versa, optamos por afirmar que ambos sejam autônomos, sendo possível o estudo do texto dramático desvinculado da encenação" (PASCOLATI, 2019, p. 86). Ainda assim, a autora ressalta que, mesmo durante a análise de um texto dramático sem o apoio cênico, é necessário manter-se atento "à fluidez dos diálogos e às indicações cênicas”, uma vez que são esses elementos textuais que trarão a "compreensão da ação que se desenrola" (p. 86), e que requerem um esforço imaginativo ainda maior do leitor, que não tem o aparato da representação para lhe ilustrar a cena.

Pascolati ainda diz que, ao fim de um espetáculo, o que resta é "o texto a ser estudado, analisado, relido, reinterpretado, reencenado" (PASCOLATI, 2019, p. 87), sem levar em consideração a representação que acaba de acontecer ou as que virão pela frente. Resta, então, o texto produzido pelo autor. Ou, em alguns casos, como neste, o texto elaborado pelo tradutor.

Susan Bassnett (1991) comenta que a tradução do texto teatral se divide em dois pontos: deve-se estudar a dramaturgia do texto de partida, que pode já dar indícios da interpretação cênica, mas também deve-se traduzir o texto já pensando na cena sem a influência de seus criadores. Zurbach (2021) resume os estudos iniciais de Bassnett, ao que ela chama de tradição "clássica da tradução do texto de teatro", como "o processo de interpretação e reescrita de um texto de partida convencional, que termina no texto de chegada entregue para a publicação ou para a interpretação em cena" (2021, p. 10)
Entendemos aqui que, embora o texto teatral e sua realização cênica possam ser estudados e discutidos separadamente, no momento de sua tradução, eles devem ser, segundo a reflexão proposta por Christine Zurbach (2021), "from page to stage" (p. 4). Na discussão de Zurbach, a autora ainda menciona as "mudanças estéticas introduzidas no campo da arte teatral [...] que alteraram as relações entre o texto e a cena e abriram a arte do teatro para as outras artes", permitindo assim que o teatro expandisse sua "dimensão performativa" (p. 6-7) e que o trabalho da tradução se associasse a um processo de integração de linguagens e artes.

Vemos essa nova relação entre o teatro e outras expressões da arte na obra teatral de Alberti de 1956: o autor, ao mesmo tempo em que não reduz o texto, - o texto, por si só, ainda é importante para que a mensagem e a reflexão central sejam transmitidas -, utiliza os quadros e gravuras de outros pintores europeus para contar sua história. Em Noche de Guerra, Alberti consegue equilibrar o uso de textos e o uso de referências externas, não sofrendo com o "exagero dos efeitos de encenação", como é criticado por Zurbach.

Justamente pelo uso de tais referências, observa-se no texto original de Alberti que o leitor (brasileiro, principalmente, que foi o nosso foco) poderia ter dificuldade de visualizar e entender o contexto da peça. Os quadros usados por Alberti têm suas próprias histórias e essas histórias somam-se à constituição dos personagens da peça. Observa-se que a obra carrega diversas referências conhecidas do povo espanhol: algumas artísticas, outras culturais e outras históricas. Com a tradução, pretende-se trazer a obra para o conhecimento de outros povos, que nem sempre têm conhecimento do que foram os períodos de guerra que a Espanha viveu, ou que também não têm conhecimento das obras dos diversos pintores que dialogam com o texto de Noche de Guerra. Por isso, quando a ideia da tradução começou a tomar forma, surgiu a necessidade de criar um estudo introdutório que antecedesse à peça.

Neste estudo, inserimos informações que guiam o novo leitor não só para a leitura da peça como 
também pela história da Espanha. Poucos brasileiros têm ou tiveram a oportunidade de conhecer o Museu do Prado e de entender a importância histórica e artística que o lugar possui. Essas informações, dentre outras, estão presentes no estudo introdutório, a fim de guiar o público brasileiro para um melhor entendimento da peça, seja ele um leitor contumaz ou um apreciador das artes cênicas.

A problemática aqui é: como se deve traduzir uma obra teatral que tem, em sua dramaturgia, aspectos pictóricos que compõe o texto? Essa discussão vai além, principalmente quando se leva em consideração uma revolução das artes dramáticas no século $X X$, onde o texto começou a perder sua essencialidade e começou a dar lugar a outros elementos cênicos. Isso, claro, no palco. Bassnett (1980) conta que, na história da tradução teatral, sempre existiram duas formas de se traduzir um texto: uma delas trata o texto como sagrado, na qual o tradutor esforça-se para que o texto de chegada tenha o mesmo valor poético que o texto de partida; e a outra, seria a de que o tradutor "adapta" o texto à língua de chegada. A segunda maneira se mostra mais próxima às convicções de Bassnett, que discorda, neste artigo, da existência da "performability", que supostamente impediria uma tradução eficaz do texto teatral. Essa maneira "infiel" de se traduzir o texto, defendida por Bassnett, pode acontecer em esferas diferentes: tanto durante o ofício do tradutor, ao trabalhar com o texto, como também durante o processo de adaptação da companhia teatral, que pode ter que reduzir ou aumentar o texto para que ele seja inteligível ao seu público-alvo. (BASSNETT, 1991, p. 105-106)

Encontramos na discussão de Bassnett um possível diálogo com Jorge Luís Borges (1926), que defende que a tradução deve causar a identificação do leitor. Para ele, a obra não deve manter-se literalmente fiel à original, mas sim abrir portas ao novo leitor (e espectador, nesse caso específico) que tiver acesso à obra traduzida, para que ele possa relacionar-se e entender as possíveis intenções do autor na produção original de sua obra (BORGES, 1926, p. 1). Nesse sentido, durante o processo de tradução de Noche de Guerra, optamos por fazer alterações que se mostraram pertinentes para que o texto de chegada fosse igualmente palpável ao leitor brasileiro como o é para o leitor espanhol.

Acreditamos que, para além da procura de palavras que transmitam a ideia da obra, a tradução para o teatro deve ser ainda mais cuidadosa. Como apontado por Araújo, Leandro e Barbosa, "a palavra oralizada é efêmera, irrecuperável" (2007, p. 106), então, quando se traduz pensando tanto na melhor versão do texto em sua língua de chegada quanto em sua encenação, a escolha das palavras deve ser certeira: havia a necessidade de se escolher palavras que, ao mesmo tempo, mantivessem a proposta original do autor, se aproximassem do leitor brasileiro e, ainda, tivessem o mesmo efeito caso representadas em um palco. É preciso pensar em um texto que fosse claro em sua leitura e em sua representação.

\section{Processo de tradução de Noche de Guerra en el Museo de Prado}

Noche de Guerra conta com ricos detalhes e sutis referências que foram percebidos a partir de uma leitura crítica. Observamos que no início do texto, antes do início da peça, que quando os personagens são apresentados, Alberti já indica que recorrerá a diversos quadros que darão vida às suas personagens. Grandes marcas intertextuais começam a aparecer mais adiante no prólogo, um monólogo em que o autor se transforma em personagem e quebra a "quarta parede" do teatro para comunicar-se diretamente com o leitor/espectador, a fim de situá-lo. Ao longo do desenvolvimento do prólogo, Alberti sugere, em suas notas de orientação à encenação, que as imagens, os quadros e as gravuras, sejam projetados. Já aí começa-se a entender que elas terão grande importância na peça.

Evidenciou-se a necessidade, para dar início à tradução, de realizar uma pesquisa acerca dos temas e obras abordados na peça por Alberti: o contexto das guerras, a relação interartes que ele estabelece em seu texto, quais as pinturas e gravuras utilizadas e as formas como influenciam os sentidos da peça. Tudo foi feito para que se pudesse produzir uma tradução que aproximasse o público-alvo da obra de Alberti, levando 
em consideração que nem todas as pessoas brasileiras têm o conhecimento necessário sobre a história espanhola para aproveitar a obra em sua completude. Esse estudo introdutório foi divido em quatro partes: na primeira, explicamos quem é o autor e em qual contexto ele se inseria, na segunda, mostramos a discussão intertextual e interartes que nos levou a entender a importância de traduzir a obra. Já na terceira parte, apresentamos a peça, de maneira que dialogasse com as informações históricas já inseridas e, por fim, na quarta parte, explicamos a partir de qual perspectiva a tradução foi feita.

Como o intuito desta tradução era de se traduzir o texto de Rafael Alberti de forma que ele pudesse ser compreendido e aprazível para o público brasileiro, a opção por criar as notas de rodapé foi o passo seguinte a ser tomado. Para além de informações históricas, optamos por adicionar notas que também explicassem quem foram os personagens mencionados no decorrer da história, já que personagens históricos da Espanha são recorrentes na peça de Alberti.

Pode-se observar esse tipo de referência textual no monólogo do prólogo, por exemplo:

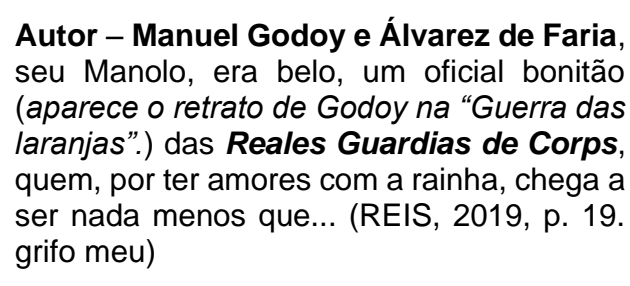

Nesse trecho, o autor-personagem cita um personagem histórico da Espanha que possivelmente é desconhecido pelo público brasileiro. Ao dizer seu nome, observa-se junto ao texto, a indicação cênica de projeção do retrato do personagem, o que promove a relação interartes e facilita o diálogo cênico que Alberti nos propõe: o quadro aparece no mesmo momento em que Godoy é citado, então o público e os leitores podem já identificar quem é a pessoa referida. Para além da tradução da fala, essa foi uma das ocasiões em que se viu necessária a criação de uma nota de rodapé. Optamos por adicionar duas notas nesse trecho: uma para explicar quem foi Manuel Godoy, chamado pelo autor-personagem pelo apelido Manolo, e, posteriormente, adicionou-se uma outra nota que explica o que eram as Reales Guardias de Corps. Neste caso, o termo, por se tratar de nome próprio, não foi traduzido, embora tenha sido explicado na nota de rodapé referente.

Durante a peça, ganham destaque os quadros e gravuras de Francisco de Goya (1746-1828). Essas obras remontam às guerras napoleônicas, vividas no século XIX, na Espanha. Para a tradução, então, foi necessário desenvolver um estudo não somente sobre as obras e sobre o pintor como também do período que elas retratavam. Nota-se como através de quadros como Los Fusilamientos de 3 de Mayo en la Moncloa (1814) ou as gravuras da coleção Los desastres de la Guerra (1810-1815), Alberti busca na Espanha do século XIX personagens que defenderão a Espanha do século $X X$.

O primeiro quadro de Goya a surgir na peça, o Los Fusilamientos de 3 de Mayo en la Moncloa, aparece já com a descrição que o autor-personagem fornece de um povo espanhol que se posiciona frente à Guerra Civil:

Milicianos dos primeiros dias, homens do nosso povo, como estes que Goya viu cair, ensanguentados, sob as balas dos fuzileiros napoleônicos, ajudaram no salvamento das obras célebres. 1808. 1936. (REIS, 2019, p. 16)

Nesse trecho há duas datas: uma se refere às guerras napoleônicas e a outra à Guerra Civil. O povo espanhol (público-alvo de Alberti) conhece e mantém viva a memória dessas datas. No entanto, questionamo-nos aqui, será que o nosso público-alvo, o leitor/espectador brasileiro, tem conhecimento de quando a invasão de Napoleão ocorreu na Espanha? Será que há o conhecimento de como essa invasão aconteceu? Como diz Newmark (2010), "El principal objetivo que se pretende con la traducción de una obra de teatro es poder representarla con éxito." (p. 232). Para que uma peça possa ser bem representada, o diretor, os atores e os encenadores devem entender o que se passa com as personagens e o mesmo deve se passar com o leitor, quando a peça é lida como literatura. Pensando nisso, justificam-se, acreditamos, as notas de rodapé ao longo de toda a tradução que situam o leitor ou o ator e o diretor teatral a respeito dos contextos históricos mencionados. Como no exemplo 
citado acima, Alberti coloca as datas de 1808 e 1936 sem maiores explicações. Na tradução, adicionamos, em rodapé, que

1808 é o ano em que, durante as Guerras Napoleônicas, a Espanha foi invadida. As tropas de Napoleão Bonaparte queriam obter total domínio sobre a Península Ibérica e, para chegar a este fim, invadiu o território espanhol no ano citado. (REIS, 2019, p. 16)

Nesse caso não mencionamos na nota o ano de 1936, pois ela já tinha sido mencionada no estudo introdutório e em notas anteriores. Desta maneira, todos os que entram em contato com o texto escrito poderão entender qual a importância das datas retomadas em cena. Consideramos que as notas de rodapé não tiram a mágica do teatro e que, no nosso caso, não chegamos a produzir o que Newmark chama de "sobretraducción" (2010, p. 233), limitando-nos àquilo que o texto pedia de conhecimento do leitor. As notas de rodapé não tiram a subjetividade das personagens nem tornam o texto cansativo: são meramente explicativas para aqueles que a colocarão no palco ou para o leitor da peça como literatura. Mas os atores, ao terem essa informação, poderão dar mais consistência aos seus personagens, transferindo-lhes essa informação através de suas ações.

As pinturas e gravuras de Goya, contudo, não são as únicas que aparecem no texto de Alberti. O autor espanhol recupera, também, pintores de outras épocas da história, como Ticiano (1490-1576), trazendo pinturas como Venus y Adonis (1553-1554), ou Las Tres Gracias (1639), de Rubens. Existem também algumas obras de Velázquez, como o Retrato de Sebastião Morra (1644), e também uma pintura de Fra Angelico, Anunciación (1435). É necessário lembrar, aqui, que todas essas obras estavam expostas no Museu do Prado, lugar que teve grande influência na formação artística de Alberti. Essas obras são importantes porque retratam a história de um povo, entre representações históricas e religiosas. Para esse trabalho, mais que entendê-las, foi necessário levar ao público as informações necessárias para interpretarem as pinturas no contexto da peça.

Alberti, além selecionar e colocar as pinturas em sua peça, transformando os personagens pintados em personagens de teatro, traduz em palavras a maneira com as quais os personagens devem aparecer em seu texto. Coube-nos buscar palavras no português - nossa língua de chegada - que transmitissem a mesma importância que as escolhidas por Alberti. Antes mesmo do início do texto, ainda na indicação de quais personagens aparecerão na obra, já começamos a inserir as notas. Alberti, na lista de personagens, explica que o Anão e o Rei são os que haviam sido pintados por Velázquez. Na tradução, adicionamos em rodapé

Diego Rodríguez da Silva y Velázquez (1599-1660) foi um dos maiores pintores espanhóis. Admitido na corte do Rei Felipe IV, passa grande parte da sua vida artística pintando retratos da corte, incluindo os anões e bobos da corte. Sua obra é marcada pelas características do barroco, com contrastes muito fortes. (REIS, 2019, p. 14)

Buscamos elaborar uma breve explicação sobre quem é o pintor das telas incorporadas na peça, facilitando, assim, o entendimento do leitor quando os dois personagens aparecem.

Ao longo do processo tradutório dessa obra, optamos por abrasileirar alguns dos nomes que surgem com o desenvolvimento do enredo. O nome das obras e de seus pintores são um exemplo disso: o autor do quadro das Três Graças, Pedro Pablo Rubens, tem seu nome tradicionalmente traduzido como Pedro Paulo Rubens. Esse processo foi feito com todos os nomes que já contavam com uma versão na língua portuguesa, enquanto nomes como as Reales Guardias de Corps, que não contam com uma versão tradicional, foram mantidos em sua língua original.

As notas de rodapé, nesta tradução, também cumpriram a função de serem o veículo de tradução de alguns dos versos que aparecem na peça. As seguidillas manchegas, por exemplo, são versos que fazem parte um ritmo popular espanhol que surgiu em La Mancha, no século XV que, segundo Corrales (1995), eram usadas constantemente no teatro espanhol, principalmente a partir do século XIX. Em Noche de Guerra esse recurso é utilizado várias vezes pelas personagens que defendem o Museu. Durante a tradução, optou-se por manter os versos originais e a tradução foi apresentada no rodapé. Há um momento em que as personagens Velha 1, Velha 2 e Velha 3 (da pintura de Goya - Las Viejas, 1810) começam a entoar 
uma dessas seguidillas, acompanhadas por outros personagens. No original:

Vieja 1. - ¡Pues venga ya de ahí! ¡Vamos!

(Bailan y cantan estas seguidillas manchegas, accionando con las escobas. El Ciego las acompaña con la guitarra.)

Si el sapo no revienta por la mañana, es porque el pobrecito se ha vuelto rana. ¡Anda jaleo!

Si me cago en el sapo, también me meo.

VIEJA 2 (quebrada y cojeando). - Dicen que al sapo caben,

en la trasera,

mosquetón y cartucho

con cartuchera.

¡Anda la broma!

Ya nadie toma al sapo

por donde toma.

TORERO (entrando al baile con el estoque). - Para matar al sapo

muestro tal arte,

que no hay parte que sea

más bona-parte.

¡Anda salero!

He de matar al sapo por el trasero.

(ALBERTI, 1956, p. 34)

Nesse trecho, alguns personagens entram na música, cantando e dançando. A tradução dos versos, para que pudessem ser entendidos pelo público leigo na língua espanhola, se encontram nas notas de rodapé:

Tradução da seguidilla manchega: Se o sapo não estoura/ Pela manhã,/ É porque o pobrezinho/ Virou rã./ Anda barulho!/ Se cago no sapo/ Também mijo./ Dizem que não cabem no sapo,/ $\mathrm{Na}$ traseira,/ Mosquete e cartucho/ Com cartucheira./ Anda a piada!/ Já ninguém pega o sapo/ Por onde toma./ Para matar o sapo/ Mostro essa arte,/ Que não tem parte que seja/ Mais bona-parte./ Anda, saleiro!/ Vou matar o sapo/ Pelo traseiro./ Se alguma vez me cuspiu/ $\mathrm{Na}$ jaquetinha,/ Vou rachar o sapo/ Com minha navalha./ Anda, ronda!/ À uma bela não há sapo/ Que se esconda./ Solta o violão!/ Corta a corda!/ Sapo gordo e pançudo!/ Sapo de merda! (REIS, 2019, p. 45. Tradução nossa.)

O termo seguidillas manchegas também foi mantido, nesse caso como forma de divulgar o nome desse ritmo popular, que também não é muito conhecido em terras brasileiras. A ele, foi adicionado uma outra nota, onde explicamos o que é o termo:

"Seguidillas manchegas são um ritmo e um tipo de dança populares criados na Espanha, na região de La Mancha, no século XV. Seu ritmo se constitui em três tempos: um forte e dois fracos, e traz traços do folclore espanhol." (REIS, 2019, p. 44)

Os versos não foram traduzidos para que pudessem ser fiéis ao seu ritmo original. A tradução literal não seria próxima do público brasileiro porque não estamos acostumados com 0 jogo musical proporcionado pelas seguidillas. Uma opção à tradução seria traduzi-las para um outro ritmo popular brasileiro que fosse igualmente conhecido pelo público-alvo, mas isso seria tomar uma liberdade poética que não nos propusemos a tomar nesse momento. Entendemos que, ao manter os versos originais no texto com sua devida tradução nas notas de rodapé, conseguimos manter a mensagem principal da peça e, ainda, criar uma atmosfera que remonta à cultura espanhola, que está no cerne da peça. Para a encenação, porém, o recurso de adaptar os versos para um ritmo popular brasileiro, poderia ser um artifício interessante.

Nas palavras de Borges (1926), "el sentido de una palabra no es lo que vale, sino su ambiente, su connotación, su ademán.” (p. 256). Seguindo a ideia proposta por ele, a escolha das palavras e dos termos que foram usados na tradução foram feitas a partir de uma pesquisa acerca de termos utilizados no português brasileiro e, também, como se trata de uma peça teatral, palavras que remetem ao palco e ao ato cênico. Dialogando com os outros teóricos do texto teatral, as palavras e estruturas linguísticas foram escolhidas de maneira que, quando pronunciadas num palco, atingissem seu objetivo final, que é o de impactar o espectador, da mesma maneira que pudesse impactar o leitor da obra.

Pensando nisso, outro fator que deteve nossa atenção foram as expressões populares e palavrões que aparecem ao longo da história. Noche de Guerra retrata o povo espanhol e, mais que isso, um povo revoltado, com pouco a perder, que se dispõe a dar a vida para salvar seu país, sua casa. É de se esperar que palavrões, palavras de ordem e expressões variadas apareçam. 
Em um dos momentos finais da peça, há uma ocasião na qual uma comitiva de mutilados pelos conflitos bélicos espanhóis aparece. Um personagem misterioso é carregado pelas Velhas de Goya. Segue um diálogo, no original e a tradução:

MANCO. - ¡Rayos y truenos! ¿Qué alboroto es éste?

VIEJA 3. - No te aflijas, manquillo. Poca es la bulla para la que se va a armar cuando sepas quién soy y a quiénes traemos.

MANCO. - ¿Puede saberse a qué venís con tantos pitos y matracas en una noche como ésta?

VIEJA 3. - Te vas a mear si te lo digo.

FRAILE. - Vienes de las cloacas del infierno, de los sumideros del diablo. ¡Mascarón indecente! (ALBERTI, 1956, p. 40)

Manco - Raios e trovões! Que alvoroço é esse?

Velha 3 - Não se aflija, Manquinho. Pouca vai ser a zona que vai se armar quando descobrirem quem sou e a quem trazemos.

Manco - Posso saber por que vocês vêm com tantos apitos e matracas em uma noite como essa?

Velha 3 - Vai se mijar se eu te disser.

Frade - Vem do cu do inferno, dos sumidouros do diabo. Mascarado indecente! (REIS, 2019, p. 51)

Nesse trecho, especificamente, nos deparamos com vários elementos que foram recorrentes e que detiveram nossa atenção durante a tradução. Muitas expressões são usadas, e tivemos que as traduzir de uma maneira que soasse familiar ao público brasileiro, como é o caso do diminutivo usado em "manquillo", por exemplo, foi traduzido para "manquinho". Mais adiante, temos a frase da Velha 3 "Te vas a mear si te lo digo." No português usamos uma expressão equivalente, então não tivemos tantos problemas ao traduzir literalmente para "Vai se mijar se eu te disser". Nota-se, aqui, uma mudança gramatical, apenas. Como no português brasileiro não se usa a conjugação verbal em segunda pessoa, optou-se por patronizar no texto da peça o tratamento pelo pronome de tratamento você, acompanhado da terceira conjugação verbal.

Ainda no trecho citado, temos a expressão, falada pelo Frade, "las cloacas del infierno". A palavra cloaca, quando traduzida literalmente, significa sarjeta ou esgoto e, até mesmo, o órgão excretor da galinha. No português falado atualmente, não existe a expressão "nos esgotos do inferno" ou "nas cloacas do inferno", mas há uma expressão popular mais usada em ocasiões informais, que foi a que escolhemos colocar na tradução.

Especialmente em momentos de conflitos, é comum que as pessoas recorram a palavrões para expressar a indignação ou a raiva, como no caso do trecho citado. Optamos por traduzir com um "palavrão", já que seu uso é recorrente no texto de Alberti e, com a tradução escolhida, teríamos 0 mesmo efeito que a frase causa no texto original.

A tradução de peça de Alberti exigiu o apoio de diversos recursos, alguns bibliográficos e outros linguísticos. Além disso, foi necessário trazer ao texto traduzido o contato com a pintura e com a cultura popular espanhola. O teatro não permite os parênteses da narrativa, então, a tradução que elaboramos exigiu a adequação do texto dramático ao português, mas mais que isso, a inserção do leitor em um universo artístico por meio da tradução e dos paratextos pensados como maneira de conduzi-lo por uma cultura diferente da dele.

\section{Considerações finais}

Para introduzir uma obra literária de outra cultura e escrita em outra língua para um determinado público, cremos ser necessário fazer uma contextualização acerca de quem a escreveu e em quais circunstâncias foi escrita. Em nossa tradução e neste artigo, ao apresentar as reflexões referentes ao processo de tradução, destacamos a figura de Rafael Alberti, indicando quais os seus campos de atuação dentro das Artes, sua trajetória de vida e aspirações políticas. Paralelo a isso, mencionamos brevemente, 0 momento histórico que a Espanha viveu durante os anos 1930 e toda as implicações que isso teve para a 
história do país e para a escrita da peça Noche de Guerra en el Museo del Prado.

Entendemos que grande parte dos brasileiros não têm contato com a história da Espanha e com as obras criadas durante e em decorrência da guerra que marcou o país. Por isso, a tradução contou com a criação de um estudo introdutório que cumpre a função de imergir o leitor/espectador na obra que dialoga com um momento histórico específico.

Não foi um processo fácil nem rápido, visto que a obra retrata um povo dividido que luta pelos seus ideais ao mesmo tempo em que tem que lidar com as consequências de uma guerra. Para além disso, a peça conta com a personificação de personagens históricos espanhóis, que voltam à obra para também defender seu ponto de vista. Nos deparamos com expressões e ritmos populares, palavrões, jargões utilizados por um povo espanhol, e isso resultou em mais uma pesquisa, para que pudéssemos aproximar a tradução de nosso público-alvo.

Embora não esteja publicada, a Tradução Crítica de Noite de Guerra no Museu do Prado foi o resultado de um ano de pesquisa e estudo que resultaram nesse artigo, que nos deram a oportunidade de refletir e analisar as dificuldades que vivenciamos durante o processo de criação. Mais do que traduzir uma peça teatral, esse trabalho exigiu que traduzíssemos pinturas e gravuras de grandes nomes das artes plásticas, como Goya e Velázquez, e que entrássemos em contato com expressões e ritmos populares - tanto em espanhol (nossa língua de origem), como em português (nossa língua de chegada), a fim de criar um texto que fosse próximo e agradável para o leitor brasileiro.

Consideramos que essa obra traduzida abre novas portas para a peça de Alberti. Com sua versão em português, o acesso à novas dramaturgias e narrativas teatrais se torna possível, bem como a inserção da obra em aulas de história, artes plásticas ou literatura, uma vez que ela abrange essas três áreas. Para além disso, serve como ampliação das possibilidades do fazer teatral no Brasil, que ainda conta com exportações europeias que nem sempre causam a identificação e comoção do público, por não serem fruto de um processo de tradução aprimorado.

\section{Referências}

ALBERTI, Rafael. Noche de Guerra en el Museo de Prado (Águafuerte, en un prólogo y un acto). Buenos Aires: Losange, 1956.

ARAÚJO, Ana Ribeiro Grossi; LEANDRO, Maria Clara Xavier; BARBOSA, Tereza Virginia Ribeiro. As dificuldades de traduzir para teatro: o prólogo das Eumênides de Ésquilo. Cadernos de Tradução, Universidade Federal de Minas Gerais, v. 2, ed. 20, p. 101-124, 2007.

BASSNETT, Susan. Translating for the Theatre: The case against Performability. TTR: traduction, terminologie, rédaction, [s. I.], v. 4, n. 1, p. 99-111, 1991. DOI 10.7202/037084ar. Disponível em: http://id.erudit.org/iderudit/037084ar. Acesso em: 12 maio 2021.

BUADES JUAN, Josep Maria. Raízes espanholas da Guerra Civil. In: MEIHY, José Carlos Sebe Bom (org.) Guerra Civil Espanhola: 70 anos depois. São Paulo: EDUSP, 2011. p. 81-94.

BORGES, Jorge Luis. (1926/1997): Las dos maneras de traducir. In: Textos recobrados. Buenos Aires: Emecé, 1997.

CARVALHAL, Tania Franco. Intertextualidade: a migração de um conceito. Via Atlântica, número 9, jun. 2006, p. 125-136. Disponível em:

$<<$ http://www.revistas.usp.br/viaatlantica/article/view/5004 6/54174 >> Acesso em: 04 maio 2021.

CARVALHO, Mayra Moreyra. Transcendente e histórica: a poesia de Rafael Alberti escrita durante a Guerra Civil Espanhola. Caracol, n. 11, p. 134-175, 2016. Disponível em:

https://www.revistas.usp.br/caracol/article/view/118333. Acesso em: 04 maio 2021.

CASANOVA, Julián; GIL ANDRÉS, Carlos. Breve historia de España en el siglo XX. Barcelona: Editorial Planeta, 2012.

CERIGIOLI, Marcelo Maciel. Rafael Alberti: Leituras do Museu do Prado. Dissertação de Mestrado. São Paulo, FFLCH/USP, 2001. Disponível em: $<$ www.teses.usp.br/teses/disponiveis/.../2011 MarceloMa cielCerigioli.pdf> Acesso em: 04 maio 2021.

CORRALES, Eloy Martín. La lucha por los escenarios y el público catalán: el arraigo popular del flamenco y de los toros frente a la oposición de la burguesía industrial y el catalanismo. In: STEINGRESS, Gerhard; BALTNÁS, Enrique. Flamenco y Nacionalismo: Aportaciones para una Sociología Política del Flamenco, Universidad de Sevilla, 1995, p. 247-266.

MAGALDI, Sábato. Iniciação ao Teatro. São Paulo: Editora Ática S.A., 1994. 
MOHALLEM, Meire de Lima; OLIVEIRA, Katia Aparecida da Silva. História, poesia e pintura em Las 4 Estaciones de Rafael Alberti. Anuario Brasileño de Estudios Hispánicos, ano 2017, v. XXVII, p. 90-101.

NEWMARK, Peter. Manual de Traducción. Madrid: Ediciones Cátedra, 2010.

REIS, Guilherme Assis dos. Tradução Crítica de Noite de Guerra no Museu do Prado. Trabalho de Iniciação Científica. Universidade Federal de Alfenas, 2019. 69 p.

RYNGAERT, Jean-Pierre. Introdução à análise do teatro. Tradução de Paulo Neves. São Paulo: Martins Fontes, 1996.

ROSENFELD, Anatol. O teatro épico. São Paulo: Perspectiva, 2008.

PASCOLATI, Sônia. Operadores de Leitura do Texto Dramático. In: BONNICI, Thomas; ZOLIN, Lúcia Osana (org.). Teoria Literária: Abordagens históricas e tendências contemporâneas. Maringá: Eduem, 2019. p. 85-105.

OTTONI, Paulo. Tradução a prática da diferença. Campinas: ed. UNICAMP, 2005.

PEREIRA, Victor Hugo Adler. Tradução teatral: o Mercado, o Fetiche e a rebeldia na Cultura. In: BERNARDO, Gustavo (org.). As Margens da Tradução. Rio de Janeiro: Editora Caetés, 2002, v. 1, 96-116.

ZURBACH, Christine. A tradução de teatro (também) é literária. In: MONIZ, Maria Lin; GIL, Isabel; LOPES, Alexandra (Orgs.). Era uma vez a tradução. Lisboa: Universidade Católica Editora, ano 2021, p. 84-93. Disponível em: https://dspace.uevora.pt/rdpc/handle/10174/29306. Acesso em: 12 maio 2021.

\section{COMO CITAR ESSE ARTIGO}

DOS REIS, Guilherme Assis; OLIVEIRA, Kátia Aparecida da Silva. Reflexões sobre um processo de tradução: história, teatro e pintura em uma obra de Rafael Alberti. Signo, Santa Cruz do Sul, v. 46, n. 87, sep. 2021. ISSN 1982-2014. Disponível em: doi:https://doi.org/10.17058/signo.v46i87.16665. 